\title{
DEVELOPMENT OF ALTERNATIVE TOURISM IN KOSOVO - PEJA REGION
}

\author{
Bekë KUQ ${ }^{1}$, Elvis ELEZAJ ${ }^{2}$, Petrit HASANAJ ${ }^{3}$ \\ ${ }^{1,2}$ University "Haxhi Zeka", Peja, Kosovo \\ ${ }^{3}$ University of Applied Sciences, Ferizaj, Kosovo \\ Corresponding author's e-mail: elvis.elezaj@unhz.eu
}

\begin{abstract}
In the concept of alternative tourism, the dynamic growth of cultural tourism can be explained by the fast growth of demand for trips to various cultural attractions and amenities. Alternative tourism is a form of tourism that is not well-known and promoted in our country, but which presents high economic development potential. Alternative tourism is based on the use of natural potentials and cultural heritage and encourages interaction with nature, people and community. Peja District is an important tourist destination in Kosovo especially in rural areas, which are popular and frequently visited by local visitors and tourists from the European Union. History, culture and tradition are the main sources of tourism development in Peja region. The position of extension, the protected environment, the fertile lands, etc. are the elements that identify the city of Peja as a tourist town, which is visited throughout the year by visitors from different countries. Such tourism will be just green, sensitive, progressive, harmonious, responsible, eco, community; all characteristics fall under the heading "alternative tourism". The goal of the paper is to provide readers with knowledge about alternative tourism in Peja municipality.
\end{abstract}

Keywords: Culture, visitors, cultural heritage, local actors, natural potentials.

\section{INTRODUCTION}

The goal of the paper is to map tourism products and services that have the highest potential for tourism development in Peja region, as well as to present the current situation and the needs of local businesses and the trend of their development. The paper presents tourism products and services categorized on the basis of geographical position and tourist attributes identified during the present study. The main categories according to which the mapping of tourism products and services have been carried out are the following: natural, cultural, culinary and agro-tourist heritage. Mass tourism is represented by a large number of people searching for vacation in famous, touristic and cultural destinations. Alternative tourism is occasionally labelled as "tourism of unique interest" and is often expressing alternative modalities of tourism that emphasise the understanding, way of life, natural and local environment of the inhabitants. Rural tourism provides precious endowment to local entities. Its endowment might be counted not only financially, but also through creation of new jobs, contribution to maintaining finances and encouragement in adopting new work practices. All rural entities that are not directly entangled in tourism may profit from tourism activities by creating close cooperation with tourist locations where local food and beverages might be 
used as a way of tourism. Rural tourism enables the widening of supplementary work, such as service stations and new entrepreneurs established to look after tourist requirements, hosting services, recreational activities, arts / crafts, etc. The mountain tourism is occasionally advertised as a growing and excitatory industry, at the same time suitable for energetic and enthusiastic young people. Rural communities should have a hosting hub where tourists may request details on local attractions, activities and catering and ask people with knowledge of the area.

\section{METHODOLOGY}

The methodology used to conduct the study is based on the combination of primary and secondary data. According to Therese L. Baker (Doing Social Research), the secondary data are the data extracted from the study examinations that other researchers have done about this object. The provision of these data was made possible through a review of the literature in the field of tourism and sustainable development. A number of methods have been used to conduct this study, such as research, statistical methods, direct field observations and cartographic methods. The research method was applied for the use of all existing literature on the development of tourism according to different authors and the development of alternative tourism in Peja.

\section{HISTORY OF PEJA REGION}

History, culture, tradition, natural resources, geographical extension position, environmental protection, fertile lands are the key features that make Peja as a tourist centre, which is visited by visitors throughout the year (Municipality of Peja - Tourism sector). The town has a very antique history and is known in the Republic of Kosovo as a tourist city. Various notes indicate the existence of this city in an organised manner since Illyrian times, and Peja is also mentioned as one of the main cities and the connecting route of numerous trade caravans that have travelled from Venice and Ragusa (Old Dubrovnik).

Visiting Peja means traveling through different times, ranging from the Illyrian, Byzantine, Ottoman, World Wars to the present day, i.e., during your visits to this city you will find traces of different historical buildings which have remained from different times. Although the remains have been covered and no archaeological research has been done, one can still begin with the history of the city of Peja from the Illyrian period (old archaeological stones can be seen in the ethnographic museum), then visiting religious sites such as mosques, catholic and orthodox churches, shrines, Haji Bey's Hammam, Haji Zeka's Mill, stone-built towers in Peja, old town houses, dressing culture and old resident traditions, crafts and more. Apart from the cultural tour that Peja offers, it also has great natural resources which surround it in the northwest and are only $1 \mathrm{~km}$ away from the city centre. The largest assets are the mountainous region of Rugova where the Rugova Gorge, Lumbardhi, lakes above $1860 \mathrm{~m}$ altitude, caves, numerous water springs, waterfalls along the gorge, rich flora and fauna, mountain peaks above $2000 \mathrm{~m}$ are offered to explore by visitors. One of the main attractions of the city of Peja is the $30 \mathrm{~m}$ long Drini 
Waterfall that is visited throughout the year by numerous local and foreign visitors and which is just a puzzle of Albanian Alps (kk.rks- gov.net/peje/turizmi). What is more important is that in Kosovo the climate is very favourable for tourists because four seasons are adjusted in accordance with official calendar and in rare cases the climate happens to be different, for instance, the winter season is snowy each year (Kuqi, 2018). The tour guide is the ambassador of the nation, or at least an ambassador for their area (Rahmiati, Othman, Tahir 2020).

\section{ECONOMIC AND NATURAL POTENTIALS IN PEJA REGION}

Currently, the main economic incentives of Peja are tourism, trade, transport, agriculture, food and beverages industry and building materials. In the city of Peja and Rugova tourism has received a special emphasis since 2000. The new infrastructure is fully dedicated to tourism development. New buildings have been built, especially hotels and restaurants along the roads linking Peja with Rugova and Peja with Radac. Today, Peja is one of the most important shopping and tourist centres of Kosovo. Peja and its surroundings are one of the major actors contributing to the country's economic development (Directorate for Economic Development - Sector of Tourism - Peja).

\section{ALTERNATIVES TO TOURISM DEVELOPMENT}

During the process of drafting a tourism development policy and plan, it is crucial to bear in mind various forms to develop tourism that suits the tourist country or region. In many cases, different forms of tourism development may be appropriate for a particular country or region and depend on existing specific resources, their location, tourism market, adapted tourism policies and other included factors (Gorica \& Vela, 2007). Everything that is expressed by the tour guide is considered by tourists as a reflection of the character of the local community and anything delivered by a tour guide will be trusted by tourists as the knowledge that will always be remembered as they return home (Atonk, 2017).

\section{HERITAGE SITES IN PEJA REGION}

Heritage sites and traditions presented below and divided by municipalities were assessed in 2011 during the on-site integration work of the Heritage Plan for the region. The presented heritage sites are only a sample of the region's rich and diverse heritage. Continued work under the Heritage Plan will further enrich these lists on the basis of progressive growth planning. This early and progressive engagement of the community with heritage sites and traditions is a distinctive feature of the process of the Heritage Plan implemented in Kosovo (MCYS - 2019). The main factors ensuring the production of the tourism services community are natural resources, historical, artistic and cultural assets, human resources (Bakiu, 2008). 


\section{MATERIAL HERITAGE OF PEJA REGION}

The material heritage of the region is represented by Bajrakli Mosque, Haji Bey Hammam, Haji Zeka Mill, Tahir Begu Han (dosshouse), Goskay Tower, Qamil Limani Tower, Zenel Bey Tower, Kurshumli Mosque, Old Bazaar, Patriarchate of Peja. The city with its suburbs is inhabited by about 100000 people, whilst the city alone has about 60000 inhabitants. In the last decade there was a large concentration of population in the city due to better living conditions and employment. The city itself is quite attractive. There you can come across different cultures. The population is mixed, where Albanians make up $90 \%$ of the structure, while Serbs, Montenegrins, Bosnians, Roma, etc. make up $10 \%$ of the population structure (Tourist Information Guide, Municipality of Peja, 2018).

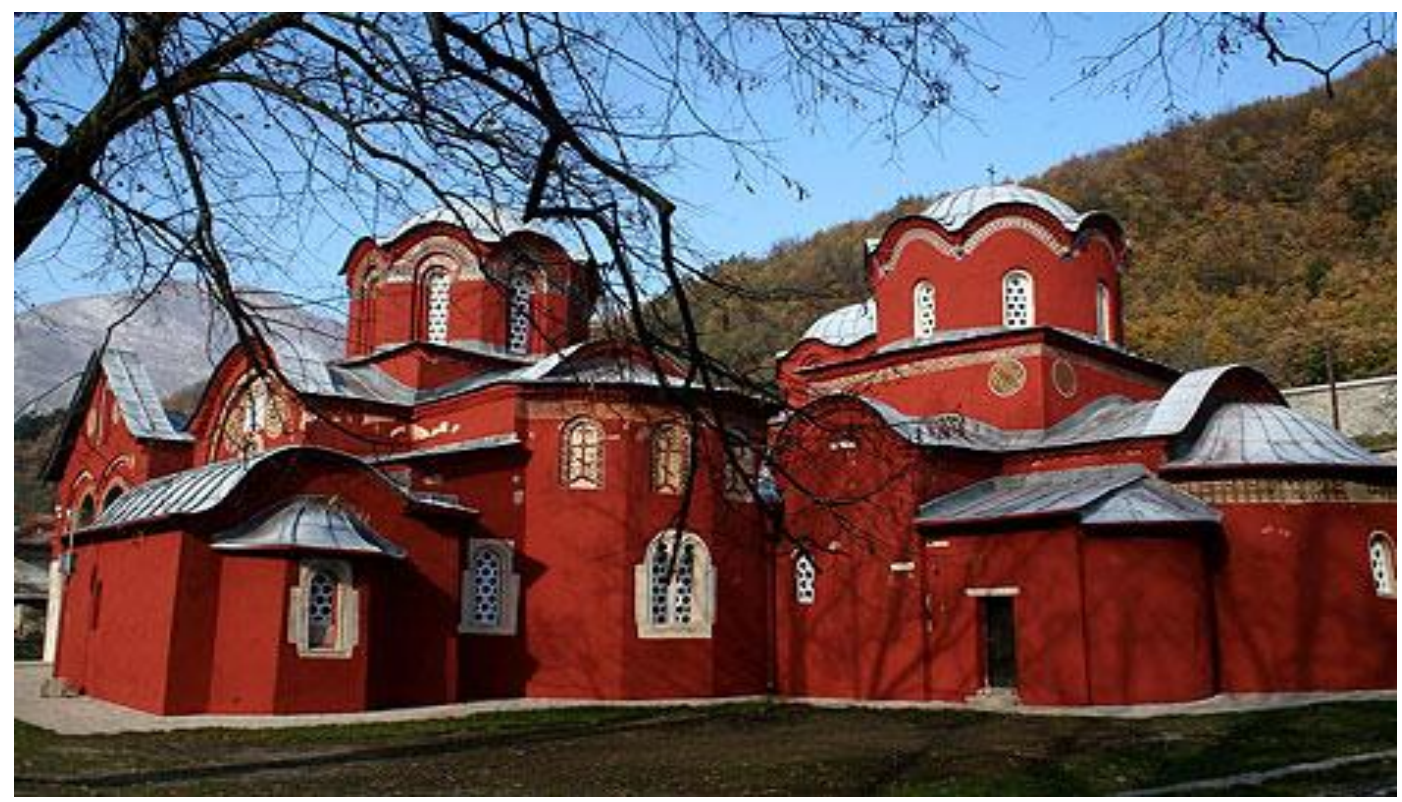

Fig. 1. Patriarchate of Peja (Municipality of Peja, 2018).

Built in 1471, Haxhi Zeka is buried in its yard. Its tower, or the Tower of Pasha, is also well known. Just 300m from St. Catherine Church on the Rugova Gorge Road there is the Orthodox Church that enjoys the status of Patriarchate. Its beauty and importance are recognised by UNESCO; it is praised as heritage treasure and is internationally protected. To visit this church and take some pictures, one must have special permission from the church.

Built during the Ottoman Empire in the 14th century it consisted of four parts: the Grand Bazaar, the Long Bazaar, the Okoli and the Shrub Bazaar. Nearby, there are hundreds of stores that provide handicrafts. Since the 19th century, architectural complex of Haji Zeka's Mill now is open to visitors. 


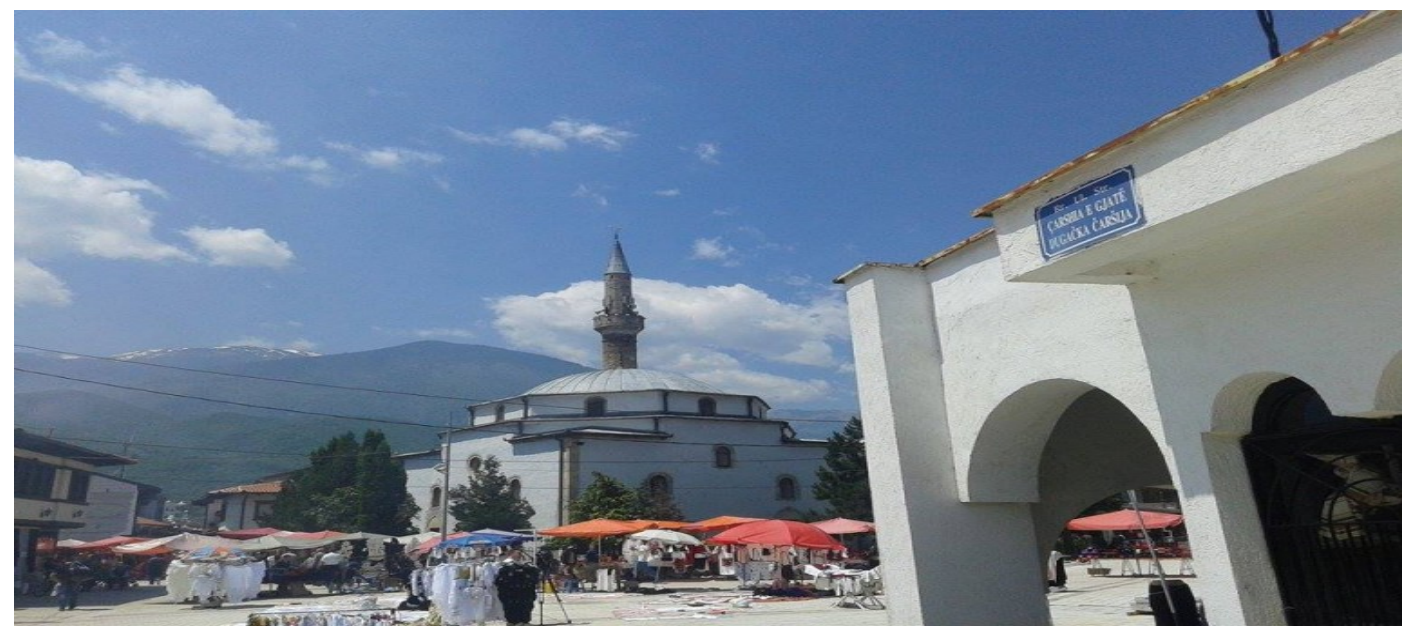

Fig. 2. Mosque Kurshumli (Municipality of Peja, 2018).

The first industrial water mill, which belongs to the Austro-Hungarian period, where the entire region has been grinding wheat and producing flour, is under state protection and it serves various exhibitions and visits. Everyone can be a guest, even for free. Since 1977, it is under state protection as a historical monument.

\section{NATURAL HERITAGE OF PEJA MUNICIPALITY}

The Rugova Gorge is a canyon near Peja and it is about $25 \mathrm{~km}$ (16 mi) long and about $1000 \mathrm{~m}$ deep. The Gorge is top listed canyon amongst those with the highest and longest depth in Europe. Rugova is considered to be one of the longest and deepest canyons in Europe. The Gorge is formed by water erosion and the withdrawal of glaciers in Peja. The Peja-Bistrica Lumbardhi (river) passes through the canyon. Since 1985, Rugova Gorge has been included in the list of monuments and it is under protection as a monument with values of natural and national heritages.

In the spring at the foot of Mount Rusolia from Radavc Cave, at $586 \mathrm{~m}$ above sea level, it creates a beautiful waterfall. The wellspring reaches $30 \mathrm{~m}^{3}$ per second, which also creates a waterfall 30 meters high. The area of Lumbardhi River in Kosovo is $4265 \mathrm{~km}^{2}$.

A fundamental challenge for tourism development in Kosovo is the lack of statistical data on the sector; therefore, collecting these data is not easy and many other resources are needed. As can be seen in Fig. 1, the interest of visitors is great because in Kosovo the citizens are hospitable to tourists. The specific statistical data of tourism are not collected and mentioned in the reports of the Kosovo Agency of Statistics (KAS), and the only contribution of the KAS to the tourism sector is the reporting of Hotel Statistics data.

Below is a comprehensive presentation of data available from the KAS and Kosovo Border Police, which are collected to present the current situation mainly in relation to the arrival of visitors / tourists, the number of nights spent, accommodation capacity and use, and market share by region (Dula, 2018). 


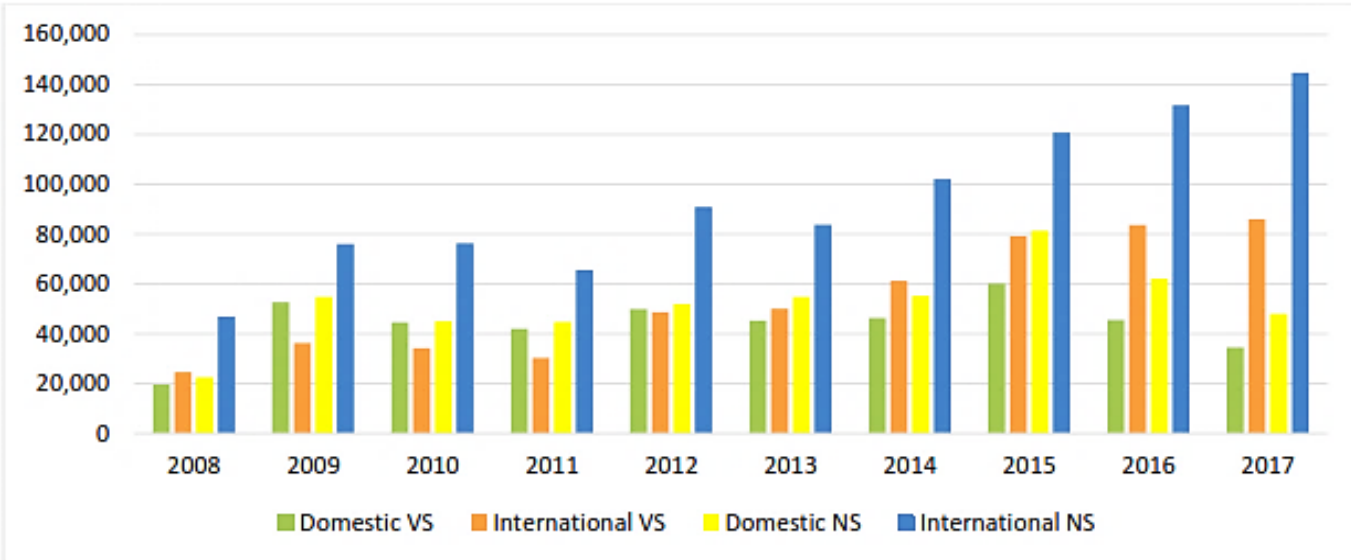

Fig. 3. Number of local and international visitors and nights spent (developed by the authors adapted from the KAS, 2018).

The number of local visitors (Fig. 3) and the nights spent fluctuated between increase and decrease until 2014, and in 2015 reached the maximum number for the given time period. Between 2015 and 2017, there was a significant decline in the domestic market by more than $24 \%$ from year to year $(\mathrm{VnV})$. On the other hand, international visitors increased in number throughout the period, with the largest increase between 2015 and 2017, and the nights spent also increased almost throughout the period by about $13 \%(\mathrm{VnV})$. Table 1 presents the revenues from tourism only for Peja based on the data of the Audit Office of Kosovo.

Table 1. Own Source Revenues 2015-2017 (National Audit Office of Kosovo)

\begin{tabular}{|l|l|l|l|l|}
\hline Entity & Year 2015 & Year 2016 & Year 2017 & Total 2015-2017 \\
\hline Peja & 3564185.29 & 3745336.55 & 3836760.98 & 11146282.82 \\
\hline
\end{tabular}

As can be seen in Table 1, the revenues from tourism in Kosovo are constantly increasing. Today tourism in the world is growing, and also in our country in Kosovo. Kosovo is trying to develop tourism on the basis of capacity, because it is not so developed due to the war in 1999. In Kosovo, the countries of the European Union have invested in the restoration of cultural, historical, etc. monuments.

\section{THE ROLE OF LOCAL COMMUNITIES AND THE IMPACT ON THE TOURISM POLICY}

Various scholars (Matarrita-Cascante, Stedman \& Luloff, 2009) conclude that in order to reach endured tourism development, local entities must engage in the decision-making process. In order to achieve long-term reliable results, local community should be active continuously rather than act just as a spectator. Inclusion of local community also provides it with a voice in decision making to improve plans, provide services and lastly to foster a sense of community by 
bringing people together that share common goals (Pongponrat, 2011). Theoretically, the role of local communities in tourism development, in the context of policy and decision making, depends on the type and level of participatory model within a tourist destination. Thus, the power of local communities to influence decision making as well as policy making will depend on the level of participatory approach operating in a particular destination. In most developing countries, decisions and policies are mainly top-down and controlled by central institutions, private sector and / or NGO. In such cases, local communities' influence is pale. Their inclusion can hardly go beyond simply just as consultation and information sharing (Scherl, Edwards, 2007). Struggles to transform tourism as a liable alternative have strongly focused on the approach to develop community, but the analysis of the differences between traditional community economic development and CBT development clearly shows that tourism continues to be driven by levels of central institutions rather than communities' interests. However, liable tourism development has been enacted as a policy approach and planning by many central institutions around the world seeking to cause minimal impact on the environment and local culture (Bansal, Kulshreshtha \& Gautam, 2009). These scholars emphasise that the notion of liable tourism becomes visible as an effort to gain precise evaluation of tourism adverse effects on local communities. Seeing that tourism may have crucial impact on economic development and diversities, deliberate planning is necessary for community's involvement (Byrd, Cárdenas \& Greenwood, 2008).

\section{CONCLUSIONS AND RECOMMENDATIONS}

In this article, we have described the development of tourism market through the alternative forms of tourism. High criticism of mass tourism and of its negative effects on destination areas gave birth to a new concept of tourism, i.e., alternative tourism. It incorporates soft tourism, small-scale tourism, green tourism, nature tourism and integrated tourism. Development and administration at the local level of the tourist destination should form the basis of sustainable development models. Environmental management problems at the local level are also affected by the infrastructure of Environmental Inspectorate in Peja region to perform appropriate control and field inspections. Many tour operators work without an environmental permit or even when they have one, they do not respect environmental regulations. Likewise, the imposition of sanctions has resulted in a practice that in most cases has not been executed due to a low number of environmental inspectors. Marketing carried out by the local government is still limited, without any effect of creating international clientele. There is no particular place in Peja for promoting tourism in Peja region. Information on tourist services and attractions is either missing or incomplete and only in Albanian. Tourist guides are not sufficiently shown and promoted. What is missing at these websites is the appropriate tourist information to guide the market regarding accommodation services (hotel information, guest houses), leisure activities (information on what can be visited, what activities can be done), etc. Moreover, tourism promotional activities are managed in an uncoordinated way. Due to the lack of realistic guidance in the field of tourism 
marketing, these activities are mainly carried out by private operators, municipal authorities and a small number of travel agencies. The impact of perceived local tourism relates to personal benefit relationships. These indicate stances of local community towards aspects of development of tourism and sustainability. At the end of this research, it is concluded that the above-mentioned aspects of sustainability are affected by the involvement of local communities in tourism planning, especially its social and cultural aspects. Involving local communities in the planning tourism shall allow policy makers to develop policies, which meet the requirements of interested parties, conveying their needs and expectations of sectorial development. The role of the public sector as a responsible structure for the whole destination management process is needed, ranging from development planning, local city management to financial management and monitoring the achievement of the set objectives. Development and management at the local tourist destination level should form the basis of sustainable development models.

In order to have a superior level of integration in the context of local destination, promoting strategies that support decentralization should be the focus of sustainable tourism. All local destination actors - local government, residents and the tourism industry - must share the common task of protecting and preserving natural and cultural heritage resources to support a coherent economy, as well as ensuring its protection for future generations. Local government needs to make sure that all stakeholders are aware of their role and responsibilities at the development stages. It is important to consider which principles of sustainable development can be implemented through community control and which need to be implemented through higher level control.

\section{REFERENCES}

Atonk, I. (2017). Basics of Tourism and Management of Tourism Destinations. The Gateway to Media Literacy and the Ambarrukmo Tourism High School Yogyakarta.

Bansal, S. P., Kulshreshtha, S. \& Gautam, P. (2009). Determinants in Destination Choice. Indian Journal of International Tourism and Hospitality Research, 3(1).

Bakiu, V. (2008). Tourism Management. Tirane, chapter IV, p. 45.

Baker, T. L. (1988). Doing social research. New York: McGraw-Hill.

Byrd, E. T., Cárdenas, D. A. \& Greenwood, J. B. (2008). Factors of stakeholder understanding of tourism: The case of Eastern North Carolina. Tourism and Hospitality Research, 8(3). https://doi.org/10.1057/thr.2008.21

Directorate for Economic Development, (2018). Sector of Tourism Municipality of Peja. https://kk.rks-gov.net/peje/turizmi/burimet-natyrore-resurset-turistike/

Dula, B. (2018). Analysis of the current situation in the tourism sector in Kosovo, April 2018. https://mti.rks-gov.net/desk/inc/media/BEE9A796-9FA3-4254-8528-AB86C722CFF2.pdf

Atonk, I. (2017). Basics of Tourism and Management of Tourism Destinations. The Gateway to Media Literacy and the Ambarrukmo Tourism High School Yogyakarta.

Gorica, K., \& Vela, F. (2018). Tourism Strategy 2007. Tirane, III, Tourist Policies, p. 60, University of Tirana.

KAS, Kosovo Agency of Statistics, (2018). Available: http://ask.rks-gov.net/sq/agjencia-estatistikave-te-kosoves/ekonomi/hotelet-dhe-turizmi (in Albanian)

Kuqi, B. (2018). Theoretical approach concerning the development of sustainable tourism as tourist destination in Kosovo. GeoJournal of Tourism and Geosites, 22(2), 489-496. https://doi.org/10.30892/gtg.22218-305 
Matarrita-Cascante, D., Stedman R., \& Luloff A. E. (2009). Permanent and Seasonal Residents' Community Attachment in Natural Amenity-Rich Areas: Exploring the Contribution of Landscape-Related Factors. Environment and Behavior, 42(2). https://doi.org/10.1177/0013916509332383

Municipality of Peja, (2018). Tourist Information Guide. Available: https://kk.rksgov.net/peje/turizmi/ [Accessed 18.01.2019] (in Albanian)

Pongponrat, K. (2011). Participatory management process in local tourism development: A case study on fisherman village on Samui Island, Thailand. Asia Pacific Journal of Tourism Research, 16(1), 57-73. https://doi.org/10.1080/10941665.2011.539391

Rahmiati, F., Othman, N. A., \& Tahir, Md. N. H. (2020). Examining the Trip Experience on Competitive Advantage Creation in Tourism. International Journal of Economics and Business Administration, VIII(1), 15-30. Available:

file://C:/Users/AP00277/Downloads/Examining\%20the\%20Trip\%20Experience\%20on\%20Com petitive $\% 20$ Advantage $\% 20$ Creation $\% 20$ in $\% 20$ Tourism.pdf

Scherl, L. M., Edwards, S. (2007). Tourism, indigenous and local communities and protected areas in developing nations: Tourism and Protected Areas: Benefits beyond Boundaries.

\section{AUTHORS' SHORT BIOGRAPHIES}

Bekë Kuqi received his Doctoral degree in Tourism from St. Clement of Ohrid University of Bitola (Macedonia). He received a Master's degree in Banking, Finance and Accounting from the University of Prishtina. He received a Bachelor's degree from the University of Prishtina, Faculty of Economics. Dr Beke Kuqi works as a Professor at the University of Haxhi Zeka, Kosovo. In August 2018, he was hired as an expert at the National Qualifications Authority.

From 2008 to 2016, Mr. Kuqi was a financial expert at the University of Prishtina and a member of the senate for two terms.

Address: St. Selmon Kuqi nr.32 Lutogllave, 30000, Peje, Kosovo

Contact: +38345504000

Elvis Elezaj obtained BSc and MSc in Economics from the University of Pristina, Faculty of Economics, Department of Management and Informatics. He obtained the Doctoral degree from St. Clement of Ohrid University of Bitola, the Faculty of Economics, Department of Management, Republic of North Macedonia. Since 2016, he has been an Assistant at the State University "Haxhi Zeka" in Peja municipality, Republic of Kosovo. Currently, he is the Chairman of the Board of Directors of MFI "Qelim Kosova", Republic of Kosovo. He had job experience as a Researcher of doing business practices and policies. He was a Supervisor at Kosovo Statistical Agency and a Coordinator at NGO IPSIA - Italian NGO.

Address: St. Ahmet Korenica, 10000, Prishtine, Kosovo.

E-mail: elvis.elezaj@unhz.eu

ORCID iD: https://orcid.org/0000-0002-2631-7837

Petrit Hasanaj received the Doctoral degree in Tourism from St. Clement of Ohrid University of Bitola (Macedonia). He obtained the Master's degree in Management and Finance from the University of Pristina. In 2008 he also completed full-time Master studies in Banking Markets at ISB/Pisa in Italy. He received the Bachelor's degree from the University of Pristina, Faculty of Economics. Petrit Hasanaj works as a Professor at the University of Applied Sciences in Ferizaj, Kosovo. In August 2018, he was hired as an expert at the National Qualifications Authority. Hasanaj has been the Dean of the Faculty of Economics at the ILIRIA College - Pristina (2018-2019), and has been engaged at the University "Ukshin Hoti", Prizren, as an Assistant and a Lecturer of Economics subjects.

Address: St. Ahmet Korenica, 10000, Prishtine, Kosovo

Contact: +38344773666

E-mail: petrit.hasanaj@ushaf.net

ORCID iD: https://orcid.org/0000-0003-1535-5835 